\title{
FROM THE FOREHEAD OF ZEUS: THE ONTOGENY OF THE IMMUNE RESPONSE
}

\author{
ARTHUR M. SILVERSTEIN \\ Baltimore, Maryland
}

\begin{abstract}
SUMMARY
Many of the most important developments that result in a fully functioning vertebrate immune system take place in the developing fetus. From a variety of gene segments there is assembled in $B$ cells a congeries of antibody combining sites, one to a cell, which form the greater part of the large repertoire of immunological specificities that characterise the system. This capability is further expanded later by somatic mutations. Just as immunoglobulin isotypes are produced sequentially (IgM, IgD, IgG, IgE, IgA) as they are read along the chromosome, so does the fetus and neonate manifest immunological competence sequentially to different antigens by employing variable region germline genes as they appear along the chromosome. The generation of $T$ cell receptor diversity is accomplished by a similar mechanism of gene segment translocations. Each stage in the lineage of $T$ and $B$ cells is associated with the appearance of unique combinations of surface molecular markers, which in $T$ cells characterise also the specialised functions of different subsets. If the immune system does not spring forth quite fully formed from the evolved vertebrate genome, as Athena did from the forehead of Zeus, ontogenetic mechanisms have made it very nearly complete.
\end{abstract}

During the past 35 years or so, the Leitmotif of immunological speculation has centred around the origin of the astonishingly large repertoire of immunological specificities. This led naturally to an interest in those ontogenetic events which might influence the maturation of the immune system during fetal (and, often, neonatal) development. But it has not always been thus; for the first 75 years (1880-1955), ontogenetic influences were not called into question. At the outset, Paul Ehrlich's

Correspondence to: Professor Arthur M. Silverstein, Institute of the History of Medicine, Johns Hopkins University, 1900 East Monument Street, Baltimore, MD 21204, USA. side-chain theory of antibody formation ${ }^{1}$ postulated that all possible specificities pre-exist as surface receptors, presumably requiring no special developmental intercession. Then, when the specificity repertoire seemed too large to support an intrinsic basis, extrinsic factors were invoked in the form of antigenic instruction of the specific antibody binding site, ${ }^{2,3}$ once again demanding the services of no special ontogenetic mechanisms.

Two developments in postwar science cáused a radical change in immunological thinking about the origins of the specificity repertoire, and each shone a spotlight on developmental processes in the mammalian fetus. The first was the discovery of the phenomenon of immunological tolerance, which seemed to imply that something occurs in the developing fetus to ensure that anti-self antibodies cannot attack tissues and organs with destructive autoimmune diseases. The second development was the finding that all protein formation involves genetic control of the amino acid sequence, causing molecular immunobiologists to focus attention on the nature and number of the fetal germline genes involved in antibody formation.

The principal conceptual architect of the new immunology was Macfarlane Burnet, whose clonal selection theory of antibody formation. ${ }^{4,5}$ (stimulated by Niels Jerne's earlier natural selection theory ${ }^{6}$ ) posed most of the critical ontogenetic questions and purported to answer many of them. Whereas Burnet paid little attention to the nature of antibody specificity or to the size of its repertoire, David Talmage addressed the former question ${ }^{7}$ and Joshua Lederberg the latter ${ }^{8}$ in detail. Lederberg suggested that the chief generator of immunological diversity is a high rate of spontaneous and random mutation in 'a gene for globulin synthesis'. This notion of a somatic generation of diversity would serve thence-

Eye (1995) 9, 147-151 @ 1995 Royal College of Ophthalmologists 
forth as the focus of a strenuous and heuristically valuable debate between paucigene theories involving much somatic mutation and/or recombination ${ }^{9}$ and multigene theories which held that everything pre-exists in the germline. ${ }^{10,11}$ As we shall see, the final outcome represents something of a compromise between the two extremes.

\section{HAEMOCYTE/LYMPHOCYTE LINEAGES}

\section{Haemopoietic Stem Cells}

It is now well understood that there develops early during fetal life a multipotential stem cell capable of giving rise to multiple lineages of blood cells. ${ }^{2}$ These stem cells have been located (with some variation in different vertebrate species) first in the yolk sac and then in the fetal liver and spleen, thence to be dispersed throughout the body. The first fork in the pathway of haemocyte differentiation is represented by the appearance from these multipotential stem cells of myeloid stem cells and lymphoid stem cells.

The myeloid stem cell and its descendants begin their activity first in the fetal liver, but quickly move to the developing bone marrow. There they produce erythrocytes, monocytes/macrophages, eosinophils, basophils/mast cells and megakaryocytes, while sufficient myeloid stem cells persist to reproduce colonies of each of these tyes under suitable conditions.

The origin of natural killer (NK) cells is thus far unclear; whether they develop directly from the multipotential stem cell or via the lymphoid stem cell pathway has not been determined.

\section{Lymphocytes and Lymphoid Organs}

$B$ Cells. These immunocytes, ultimately the producers of circulating antibody, have an exceedingly complicated ancestry. From the lymphoid stem cell comes a pro-B cell, in which immunoglobulin heavy chain V-D-J rearrangement is initiated (see below). These then differentiate to form pre-B cells, which contain intracytoplasmic $\mu$ chains. Next comes the immature B cell, characterised by the presence of IgM membrane receptors ( $\mathrm{sIg}$ ), and then mature $\mathrm{B}$ cells with both $\operatorname{IgM}$ and $\operatorname{IgD}$ receptors. Finally, antigenic stimulus activates the mature $B$ cell to form plasma cells which export large quantities of antibody to the circulation.

The earliest differentiation of $\mathrm{B}$ cell lineages occurs in the fetal liver, but then quickly shifts to the bone marrow, spleen and regional lymph nodes, where distinctive areas devoted to B cell dynamics are formed, associated primarily with germinal centres. IgA-forming B cells develop in and home primarily to the gut-associated lymphoid tissues to form the secretory immunoglobulin system. Avian species are exceptional in that they possess a hindgut bursa of Fabricius whose early excision aborts the entire B cell lineage development. The closest analogue of the avian bursa in mammals appears to reside in the bone marrow.

The several stages of $B$ cell development have been identified by the appearance either of distinctive morphological changes (e.g. cell size or nucleus/ cytoplasm relationships) or more usually by the appearance of distinctive markers of differentiation. ${ }^{13}$ We have already mentioned those involving cytoplasmic or surface Igs; of equal importance has been the development of reagents to identify surface markers that come and go at various stages of differentiation. Originally called lymphocyte (Ly) antigens from mouse studies, the advent of monoclonal techniques has permitted the identification of a variety of surface antigenic markers in the human. Theses are now organised with a 'cluster of differentiation' (CD) nomenclature. Thus, CD34 is present during the transition from lymphoid stem cell through the large pre-B cell, and CD20 from the large pre-B cell through to the mature B cell, etc. ${ }^{14,15}$ $T$ cells. The evidence is strong that most $\mathrm{T}$ cells are born in the thymus. ${ }^{16,17}$ First, thymectomy very early in life in many species prevents the appearance of $\mathrm{T}$ cells in peripheral lymphoid tissues; the same is true in congenital athymia (e.g. nu/nu mice and human DiGeorge's syndrome patients). Secondly, studies show that thymocytes labelled within the thymus actually leave it to migrate peripherally, so that $\mathrm{T}$ cells may now be considered to be thymus-derived rather than merely thymus-dependent.

The picture of $\mathrm{T}$ cell ontogeny has been best worked out in the mouse. After entering the thymus, stem cells soon express Thy- 1 surface markers and undergo extensive proliferation. At day 14 of gestation, most thymocytes are Thy $-1^{+} \mathrm{CD} 4^{-} \mathrm{CD} 8^{-}$ blast cells. Two to three days later, the cells change into small lymphocytes expressing either CD4 or CD8 or both molecules, and at the same time they express $\mathrm{T}$ cell receptors on their membranes. By day $18-19$ of the 20 day gestation period, the mouse $T$ cells appear fully functional, and population of peripheral lymphoid organs is well under way.

\section{THE IMMUNOLOGICAL SPECIFICITY REPERTOIRE}

B Cells

The precise size of the immunological specificity repertoire has been the subject of much speculation, ranging from the order of $10^{5}$ completely different antibody combining sites all the way to $10^{16}$ such sites. $^{18}$ As mentioned above, ontogenists fought with molecular geneticists over the number of genes present in the germline that encode for antibody variable regions. The geneticists suggested that the genome could not afford to devote up to $10 \%$ of its DNA to the immune response, and therefore they 
postulated initially that only a few genes, acted upon by random somatic mutations and/or recombinations, give rise to antibody diversity. For their part, the ontogenists pointed to the lack of random development of the repertoire in fetal and neonatal maturation; there appears to be a well-ordered and species- or strain-specific sequence of appearance of antibodies specific for one or other antigen, both in the perinatal mouse ${ }^{19}$ and in the larger fetal lamb. ${ }^{20}$ Molecular biological approaches disclosed a novel solution: the number of genes lay between the two extremes earlier proposed; somatic mutation and recombination both contribute to the generation of diversity; and the programmed sequence of appearance of repertoire components represents the initial utilisation of the most proximal germline variable region gene segments as read down the chromosome. ${ }^{21}$

Genetics of Specificity Diversity. The germline material encoding light and heavy chains has been best worked out in the mouse. The kappa light chain sequence includes some $100 \mathrm{~V}$ genes and 4 active $\mathrm{J}$ (joining) regions, or 400 possible combinations. For $\mathrm{H}$ chains, we assume conservatively $100 \mathrm{VH}$ genes, 4 $\mathrm{JH}$ genes and $12 \mathrm{D}$ (diversity) regions, or 4800 possible combinations. Assuming random association of $\mathrm{L}$ and $\mathrm{H}$ chains, some $2 \times 10^{6}$ different specificity combinations are possible. We may multiply this by an unknown number of recombinations and alternative reading frame variants, so that it is apparent that a fairly broad universe of immunological specificities is already possible utilising only the available germline material.

Then, to all of these gene combinations, somatic point mutations of $\mathrm{VL}$ and $\mathrm{VH}$ genes are known to occur, especially at the hypervariable regions that contribute to the antibody combining site. These mutations serve not only to expand the specificity repertoire, but play an overriding role in the maturation of the average affinity of binding to antigen of a given antibody response. As clonal selection theory predicts, those B cells with higher affinity receptors for antigen will be more efficiently selected for activation by that antigen.

Isotype Switching The presence in serum of various immunoglobulin isotypes (e.g. $\mathrm{IgM}, \mathrm{IgG}, \mathrm{IgA}$ ) suggested that different genes control the expression of the different heavy chain constant regions. With the finding that isotype switching occurs in a single clone of $\mathrm{B}$ cells of the same specificity, ${ }^{22}$ it became apparent that to a certain extent spontaneously, and especially during the active immune response, the heavy chain constant region genes may be utilised sequentially. These exist on chromosome 12 in the mouse in the order $5^{\prime}-\mu, \delta, \gamma 3, \gamma 1, \gamma 2 \mathrm{~b}, \gamma 2 \mathrm{a}, \epsilon$, and $\alpha-$ $3^{\prime 2}{ }^{23}$

Allelic Exclusion. One of the central predictions of the clonal selection theory is that a single cell will produce only a single $\mathrm{H}$ - and $\mathrm{L}$-chain $\mathrm{V}$ region combination, i.e. only a homoligating $\mathrm{H}_{2} \mathrm{~L}_{2}$ antibody. But each $\mathrm{B}$ cell has two chromosomes whose $\mathrm{Ig}$ region may rearrange. How then can both chromosomes be prevented from contributing different $\mathrm{V}$ regions to the final antibody molecule? Apparently a regulatory mechanism exists at the pro-B and pre-B cell stages, wherein the formation of a $\mu \mathrm{H}$ chain on one chromosome signals the termination not only of $\mathrm{H}$ chain rearrangements on both chromosomes, but also the initiation of light chain rearrangements, with kappa generally preceding lambda. Since a comparable regulatory mechanism exists to ensure that only a single light chain is formed within the cell, allelic exclusion characterises all $\mathrm{B}$ cell activity. ${ }^{24}$

\section{T Cells}

The T Cell Receptor (TCR). Unlike B cells, the T cell does not recognise the surface areas of native proteins. Rather, the receptor is involved in a trimolecular interaction between the TCR and molecules of the host's major histocompatibility complex (MHC), in which a cleft contains an oligopeptide breakdown product of the antigen involved. Thus, whereas the B cell responds to intact antigens in solution, the $\mathrm{T}$ cell responds to antigenic peptides presented on the cell surface membranes of antigen presenting cells (APCs) or virus-infected cells.

Evolution of the TCR and its functions has much in common with that of Ig receptors. The most common TCR is composed of a heterodimer consisting of an $\alpha$ and a $\beta$ chain, members of the Ig supergene family. The TCR is associated with a set of transmembrane proteins collectively designated as the CD3 complex, which play a critical role in signal transduction. Like Ig light and heavy chains, repertoire diversity ${ }^{25}$ in the TCR $\alpha$ and $\beta$ chains is generated by multiple combinational possibilities of $\mathrm{V}$ and $\mathrm{J}$ exons in the former and of $\mathrm{V}, \mathrm{D}$ and $\mathrm{J}$ exons in the latter. Unlike Ig genes, somatic mutation appears not to play a significant role in the generation of TCR diversity. Allelic exclusion is a characteristic of the ontogeny of the TCR, as it is of the Ig receptor of B cells.

TCR Function. As mentioned above, the maturation of $\mathrm{T}$ cells in the fetal thymus is accompanied by the appearance of surface markers that help to define a variety of functions. Some cells differentiate to carry the CD4 marker; these respond to antigenic peptides presented in association with Class II MHC molecules. $\mathrm{CD} 4^{+}$cells play an important role as 'helper $\mathrm{T}$ cells', mediating the response of $\mathrm{B}$ cells to proteins and other T-dependent antigens. ${ }^{26,27} \mathrm{CD} 4^{+}$cells also appear to function as suppressor $\mathrm{T}$ cells in the downregulation of certain immune responses (see below). 
In addition, these cells are the main participants in mediating the inflammatory reactions associated with delayed-type hypersensitivity. Finally, these cells participate in allograft rejection where class II MHC alloantigens are involved, apparently by a combination of cytotoxic activity and cytokine release.

Those cells which differentiate to carry the CD8 molecular marker recognise antigenic peptides only in the context of class I MHC molecules. Their principal function is the cytolytic destruction of cells which present foreign peptides (e.g. viral or alloantigens) on their surface. ${ }^{28}$ Much of the action of both CD4 and CD8 lymphocytes depends on the release of groups of lymphokines which subserve a large variety of activating and down-regulating functions.

The description above of the various functions of TCRs is meant to apply only to those composed of $\alpha$ and $\beta$ chains. The functions of the rarer $\gamma / \delta$ TCRs are substantially unknown,

\section{IMMUNOLOGICAL TOLERANCE}

From the above description of the several mechanisms which have evolved for the generation of diversity of both $\mathrm{T}$ and $\mathrm{B}$ cell receptors, it is evident that nothing prevents the spontaneous generation of specificities capable of reacting with the self antigens of the host. Thus, in order to obviate the otherwise inevitable development of autoimmune diseases, a complicated set of regulatory mechanisms had to evolve in parallel. Some of these involve central ontogenetic events, while others depend upon a broad range of peripheral regulatory functions to suppress or inhibit the autoaggressive tendencies of the immune system. We shall review briefly here only those mechanisms that occur during the fetal and neonatal development of the immune system; the more general features of immunological tolerance will be reviewed extensively elsewhere in this issue.

\section{Intrathymic Selection of $T$ cells}

The concept of clonal deletion (abortion) in utero of anti-self clonal precursors was first advanced by Burnet to explain the relative rarity of autoimmune disease. While its applicability to antibody-forming B cells is open to question, it has been shown to be an important mechanism of $\mathrm{T}$ cell tolerance. From the first appearance of a TCR specific for a self peptide in the thymus, both double positive $\left(\mathrm{CD}^{+} 8^{+}\right)$and single positive $\left(\mathrm{CD}^{+} 8^{-}\right.$and $\left.\mathrm{CD}^{-} 8^{+}\right)$cells are negatively selected following interaction with their specific peptides on MHC molecules. ${ }^{29}$ These may be either self peptides, or those present as the result of intrafetal administration, thus explaining the tolerant chimaerism in non-identical twin cattle observed by Owen ${ }^{30}$ the similar experimental situation found in avian egg parabionts by Hašek, ${ }^{31}$ and the experi- mental induction of tolerance in the mouse fetus by Medawar and co-workers. ${ }^{32}$ This mechanism for the screening of anti-self-reactive $\mathrm{T}$ cells prior to their exit from the thymus is not completely foolproof, since auto-reactive $\mathrm{T}$ cells may be found in the periphery. There, they must be subject to a variety of regulatory controls (suppressor T cells, TCR modulation, idiotypic network regulation, etc.) to prevent them from inciting disease.

At the same time that negative selection of TCRs is occurring in the fetal thymus, a process of positive selection also takes place. ${ }^{33}$ This involves those receptors which show an affinity for self-MHC molecules which are found in abundance in the dense network of antigen presenting cells; however, cells with too high an affinity for self MHC would be dangerous to the host, and these are deselected. Since only $1-2 \%$ of all thymocytes are exported, it is probable that cells that are neither positively nor negatively selected are 'neglected', and die within days.

\section{B Cell Tolerance}

The existence of clonal deletion as an explanation of B cell tolerance has been debated for several decades. The initial studies appeared to demonstrate that experimental antigen-induced tolerance resulted only in tolerance of specific helper $\mathrm{T}$ cells, thus rendering the $\mathrm{B}$ cells unable to mount an antibody response. ${ }^{34}$ Since circulating anti-self B cells specific for many self antigens can be found in the circulation of normal individuals, it was assumed that no mechanism exists in ontogeny for the central induction of $\mathrm{B}$ cell clonal deletion. However, subsequent findings employing transgenic mice ${ }^{35}$ suggest that clonal deletion of anti-self B cells may occur amongst those cells displaying the highestaffinity specific receptors. As might have been expected, early treatment of the developing immune system with anti- $\mu$ antibodies results in destruction of IgM-bearing cells as they form and thus the abortion of all B cell maturation, including all Ig isotypes located further down the chromosome. ${ }^{36}$

It has become increasingly clear, however, that down-regulation of B cells is primarily concerned with events in the periphery, including such phenomena as receptor blockade, B cell anergy, anti-idiotypic suppression, antibody feedback and terminal differentiation.

Key words: B cell development, Fetal development, Immunogenesis, Molecular genetics, Ontogeny, T cell development.

\section{REFERENCES}

1. Ehrlich P. Die Wertbemessung des Diphtherieheil serums. Klin Jahrb 1897;60:299-326. (English translation in: The collected papers of Paul Ehrlich, vol.2. London: Pergamon, 1956:107-25.) 
2. Breinl F, Haurowitz F. Chemische Untersuchungen des Präzipitates aus Hämoglobin und Anti-hämoglobin Serum und Bemerkungen über die Natur der Antikörper. Z Physiol Chem 1930;192:45-57.

3. Pauling L. Theory of the structure and process of formation of antibodies. J Am Chem Soc 1940; 62:2643-57.

4. Burnet FM. A modification of Jerne's theory of antibody formation using the concept of clonal selection. Aust J Sci 1957;20:67-9.

5. Burnet FM. The clonal selection theory of acquired immunity. London: Cambridge University Press,1959.

6. Jerne NK. A natural selection theory of antibody production. Proc Natl Acad Sci USA 1955;41:849-57.

7. Talmage DW. Immunological specificity. Science 1959;129:1643-8.

8. Lederberg J. Genes and antibodies. Science 1959; 129:1649-53.

9. See, e.g. Cohn M. A rationale for ordering the data on antibody diversification. Progr Immunol 1974;2:261-84.

10. Hood L, Talmage DW. Mechanism of antibody diversity: germ line basis for variability. Science 1970;168:325-34.

11. Cunningham AJ (editor). The generation of antibody diversity. New York: Academic Press, 1976.

12. Till JE, McCulloch EA. Hemopoietic stem cell differentiation. Biochim Biophys Acta 1980;605: 431-59.

13. Witte ON, Klinman N, Howard MC (editors). B cell development. New York: Liss, 1988.

14. Uckam FM. Regulation of human B cell ontogeny. Blood 1990;76:1908-23.

15. Clark EA, Lane PJL. Regulation of human B cell activation and adhesion. Annu Rev Immunol 1991;9:97-127.

16. Miller JFAP, Osoba D. Current concepts of the immunological function of the thymus. Physiol Rev 1967;47:437-520.

17. Scollay R, Shortman K. Cell traffic in the adult thymus. In: Watson JD, Marbrook J, editors. Recognition and regulation in cell mediated immunity. New York: Marcel Dekker, 1985:3-30.

18. Inman JK. The antibody combining region: speculations on the hypothesis of general multispecificity. In: Bell GI, Perelson AS, Pimbly JH, editors. Theoretical immunology. New York: Marcel Dekker, 1978:243-78.

19. Sigal NH, Klinman NR. The B cell clonotype repertoire. Adv Immunol 1978;26:255-337.

20. Silverstein AM, Prendergast RA. Lymphogenesis, immunogenesis, and the generation of immunologic diversity. In: Šterzl J, Rihá I, editors. Developmental aspects of antibody formation and structure, vol. 1. Prague: Czech Academy of Sciences, 1970:69-77.

21. Klinman NR, Linton P-J. The clonotype repertoire of B cell subpopulations. Adv Immunol 1988;42:1-93.

22. Wabi MR, Forni L, Loor F. Switch in immunoglobulin class production observed in single clones of committed lymphocytes. Science 1978;199:1078-80.

23. Shimizu A, Takahashi N, Yaoita Y, Honjo T. Organisation of the constant region gene family of the mouse immunoglobulin heavy chain. Cell 1982;28:499-506.

24. Max EE. Immunoglobulins: molecular genetics. In: Paul WE, editor. Fundamentals of immunology, 3rd ed. New York: Raven Press, 1993:315-82.

25. Blackman MA. The T cell repertoire. Copenhagen: Munksgaard, 1988.

26. Parker DC. T cell-dependent B cell activation. Annu Rev Immunol 1993;11:331-60.

27. Fitch FW, Lancki DW, Gajewski TF. T-cell-mediated immune regulation. In: Paul WE, editor. Fundamental immunology. New York: Raven Press, 1993:733-61.

28. Berke G. The function and mechanisms of action of cytolytic lymphocytes. In: Paul WE, editor. Fundamental immunology. New York: Raven Press, 1993:965-1014

29. Kappler JW, Roehm N, Marrack P. T cell tolerance by clonal elimination in the thymus. Cell 1987;49:273-80.

30. Owen RD. Immunogenetic consequences of vascular anastomoses between bovine twins. Science 1945;102:400-1.

31. Hašek M. Parabiosis of birds during embryonic development. Cesk Biol 1953;2:265-70.

32. Billingham RE, Brent L, Medawar PB. Actively acquired tolerance of foreign cells. Nature 1953; 172:603-6.

33. Kiselow $\mathrm{P}$, Teh HS, Blumenthal $\mathrm{H}$, von Boehmer $\mathrm{H}$. Ideology of positive selection in $\mathrm{T}$ cell biology. Nature 1988;.375:730-3.

34. Chiller JM, Habicht GS, Weigle WO. Kinetic differences in unresponsiveness of thymus and bone marrow cells. Science 1971;171:813-5.

35. Nemazee DA, Bürki K. Clonal deletion of B lymphocytes in a transgenic mouse containing antiMHC class I antibody genes. Nature 1989;337:562-6.

36. Lawton AR, Asofsky R, Hylton MB, Cooper MD. Suppression of immunoglobulin class synthesis in mice. I. Effects of treatment with antibody to $\mu$ chain. J Exp Med 1972;135:277-97. 